\title{
Selectivity of registered pesticides for the corn crop on immature stages of Trichogramma pretiosum (Hymenoptera: Trichogrammatidae)
}

\section{Seletividade de pesticidas registrados para a cultura do milho sobre estágios imaturos de Trichogramma pretiosum (Hymenoptera: Trichogrammatidae)}

\section{Tatiele Pereira dos Santos ${ }^{1}\left({ }^{\circ}\right.$, Claubert Wagner Guimarães de Menezes $^{1 *}\left(\mathbb{C}^{\circ}\right.$, Carlos Henrique Batista ${ }^{1}(\mathbb{0}$, Eliane Souza Gomes Brito ${ }^{1}$, Wagner de Souza Tavares $^{2}{ }^{\mathbb{D}}$, José Cola Zanuncio ${ }^{3}$ [0]}

\author{
'Instituto Federal do Norte de Minas Gerais/IFNMG, Departamento de Ciências Agrárias, Januária, MG, Brasil \\ ${ }^{2}$ Asia Pacific Resources International Holdings Ltd./APRIL, Riau, Sumatra, Indonésia \\ ${ }^{3}$ Universidade Federal de Viçosa/UFV, Departamento de Entomologia/BIOAGRO, Viçosa, MG, Brasil \\ *Corresponding author: claubert.menezes@ifnmg.edu.br \\ Received in August 30, 2018 and approved in November 26, 2019
}

\begin{abstract}
Trichogramma pretiosum Riley, 1879 (Hymenoptera: Trichogrammatidae) is an egg parasitoid of lepidopteran pests in corn, Zea mays L. (Poaceae), in Brazil. Chemical products used in agriculture can be toxic to this biocontrol agent. The objective of the present study was to evaluate the longevity, parasitism and emergence of T. pretiosum parasitizing Mediterranean flour moth, Anagasta kuehniella Zeller, 1879 (Lepidoptera: Pyralidae), eggs treated with herbicide solutions with the active ingredients (chemical group) atrazine (triazines), paraquat dichloride (bipyridylium) and nicosulfuron (sulfonylurea). Pure distilled water was used as a negative control, and a solution of a product with $\lambda$-cyhalothrin + thiamethoxam (pyrethroid + neonicotinoid, respectively) was used as the positive control. The experimental design was completely randomized, with five treatments and 10 replicates. Anagasta kuehniella eggs were stored for two periods after treatment, 24 and 48 hours. These eggs were subjected to parasitism for two subjecting periods, 24 and 48 hours. The results were analysed statistically and classified according to the International Organization for Biological Control (IOBC). Atrazine and nicosulfuron reduced the longevity of $T$. pretiosum females. Nicosulfuron and the combination $\lambda$-cyhalothrin + thiamethoxam reduced the parasitism and emergence of this natural enemy. The paraquat dichloride-based herbicide was the least toxic and therefore represents a potential option for controlling weeds with low toxicity to the T. pretiosum parasitoid.
\end{abstract}

Index terms: Biocontrol agent; emergence; herbicide; longevity; parasitism.

\begin{abstract}
RESUMO
Trichogramma pretiosum Riley, 1879 (Hymenoptera: Trichogrammatidae) é parasitoide de ovos de lepidópteros praga no milho, Zea mays L. (Poaceae), no Brasil. Produtos químicos usados na agricultura podem ser tóxicos para este agente de controle biológico. O objetivo do presente estudo foi avaliar a longevidade, parasitismo e emergência de T. pretiosum em ovos da traça da farinha, Anagasta kuehniella Zeller, 1879 (Lepidoptera: Pyralidae) tratados com soluções herbicidas com os ingredientes ativos (grupo químico) atrazina (triazinas), dicloreto de paraquate (bipiridílio) e nicosulfuron (sulfonilureia). Água destilada pura foi usada como controle negativo e a solução de um produto com $\lambda$-cialotrina + tiametoxam (piretróide + neonicotinóide, respectivamente) foi usada como controle positivo. $O$ delineamento experimental foi inteiramente casualizado, com cinco tratamentos e 10 repetições. Ovos de $A$. kuehniella foram armazenados por dois períodos após tratamento, 24 e 48 horas. Esses ovos foram submetidos ao parasitismo por dois períodos de submissão, 24 e 48 horas. Os resultados foram analisados estatisticamente e classificados de acordo com a International Organization for Biological Control (IOBC). Atrazina e nicosulfuron reduziram a longevidade das fêmeas de T. pretiosum. Nicosulfuron e a combinação $\lambda$-cialotrina + tiametoxam reduziram o parasitismo e a emergência deste inimigo natural. O herbicida à base de dicloreto de paraquate foi o menos tóxico e, por isto, representa uma opção em potencial para o controle de plantas daninhas com baixa toxicidade ao parasitóide T. pretiosum.
\end{abstract}

Termos para indexação: Agente de controle biológico; emergência; herbicida; longevidade; parasitismo.

\section{INTRODUCTION}

Chemical products used in insect pest, disease and weed management can be toxic to natural enemies, aquatic organisms, decomposers, and pollinators (Gonring et al.,
2003; Menezes et al., 2012a; Castilho et al., 2014; Leite et al., 2016). These products are used in several crops, including corn, Zea mays L. (Poaceae), which accounts for $70-85 \%$ of the grains produced worldwide for animal feed (Couto et al., 2017). Corn crops are protected by chemicals 
applied for the control of insects and weeds, which are pests that reduce grain yield (Kozlowski; Koehler; Pitelli, 2009; Menezes et al., 2014).

Herbicides and insecticides are used in corn crops, especially in those genetically modified (GM) to be resistant to herbicides and attacked by insects not targeted by Bt (Bacillus thuringiensis Berliner, 1915; Bacillales: Bacillaceae) technology (Pellegrino; Bedini; Ercoli, 2018). Genetically modified crops are grown on more than $80 \%$ of the area cultivated with corn in Brazil (Bernardi et al., 2017). Atrazine, paraquat dichloride and nicosulfuron are herbicide active ingredients used in corn crops. Atrazine inhibits the weed photosystem and thus prevents electron transport (Chen et al., 2014). Paraquat dichloride increases the production of toxic free radicals and causes weed death by inhibiting photosystem I (Funderburk Jr; Lawrence, 1964). Nicosulfuron prevents the synthesis of branched amino acids (isoleucine, leucine and valine) by inhibiting the acetolactate synthase (ALS) enzyme in weeds (Anderson et al., 1998). Insects attacking corn crops can be managed with insecticides such as those based on the combination of the active ingredients $\lambda$-cyhalothrin and thiamethoxam. Pests such as Frankliniella williamsi Hood, 1915 (Thysanoptera: Thripidae), Mahanarva fimbriolata Stål, 1854 (Hemiptera: Cercopidae) and Spodoptera frugiperda J.E. Smith, 1797 (Lepidoptera: Noctuidae) are controlled with $\lambda$-cyhalothrin + thiamethoxam, which causes hyperexcitation in their central nervous system (Pasini et al., 2017b).

Weed management with herbicides can reduce the number of flowers used as shelter, a food source and breeding sites by natural enemies, such as parasitoids and predators (Albajes; Lumbierres; Pons, 2009; Menezes; Soares, 2016). In addition, herbicides and the additives used in their formulation, such as adjuvants, can be toxic to such organisms, including Trichogramma (Hymenoptera: Trichogrammatidae), a lepidopteran egg parasitoid (Menezes; Soares, 2016; Leite et al., 2016).

Trichogramma controls the eggs of lepidopteran pests in corn, such as S. frugiperda (Tavares et al., 2009). These biocontrol agents can be reared on a large scale with eggs of alternative hosts, such as Anagasta (=Ephestia) kuehniella Zeller, 1879 (Lepidoptera: Pyralidae), and can prevent the damage caused by hatched caterpillars (Stefanello Júnior et al., 2012; Tavares et al., 2016). Chemical products are usually applied during the day, when Trichogramma species exhibit oviposition peaks and are most exposed (Stefanello Júnior et al., 2008). Among the range of products used in corn crops, Sevin $480 \mathrm{SC}^{\circledR}$ (insecticide, a.i. carbaryl, group: naphthyl methylcarbamate) and Tiomet $400 \mathrm{CE}^{\circledR}$ (insecticide, a.i. dimethoate, group: organophosphate) are toxic, and Orthocide $500^{\circledR}$ (fungicide, a.i. captan, group: dicarboximide) and Persist $\mathrm{SC}^{\circledR}$ (herbicide, a.i. picloran $+2.4-\mathrm{D}$, groups: pyridine carboxylic acid + aryloxyalkanoic acid, respectively) are selective to Trichogramma pretiosum Riley, 1879 (Giolo et al., 2005; Leite et al., 2015).

The environmental persistence of chemical products and their toxicity to non-target organisms should be considered in biological control programmes with parasitoids (Menezes et al., 2012b; Menezes; Soares, 2016; Pasini et al., 2017a). The objective of this study was to evaluate the longevity, parasitism and emergence of $T$. pretiosum on A. kuehniella eggs treated with chemical products (i.e., atrazine-, paraquat dichlorideand nicosulfuron-based herbicides and a $\lambda$-cyhalothrin + thiamethoxam-based insecticide) used in corn crops.

\section{MATERIAL AND METHODS}

\section{Experimental site}

Insects were reared and the bioassays carried out in the Laboratório de Entomologia of the Instituto Federal do Norte de Minas Gerais (IFNMG)-campus Januária, in Januária, Minas Gerais state, Brazil, in an air conditioned room at $25 \pm 1{ }^{\circ} \mathrm{C}$ and $70 \pm 10 \% \mathrm{RH}$ and under a $12: 12 \mathrm{~h}$ (L:D, at 500 lumens) photoperiod.

\section{Trichogramma pretiosum rearing}

A T. pretiosum parasitoid colony obtained from the Insetário G.W.G. de Moraes of the Universidade Federal de Minas Gerais (UFMG) in Montes Claros, Minas Gerais state, Brazil, was used to begin the mass rearing of this insect at the IFNMG-campus Januária to obtain individuals for the bioassays. This parasitoid was reared on eggs of the alternative host $A$. kuehniella in $500 \mathrm{~mL}$ glass pots sealed with polyvinyl chloride (PVC) plastic after being sterilized in a UV chamber for $60 \mathrm{~min}$.

\section{Anagasta kuehniella rearing}

The alternative host was reared with wheat bran (Triticum aestivum L.; Poaceae) and beer yeast at a ratio of 97:3. The mixture obtained from these two products was uniformly distributed in plastic trays $(29.5 \mathrm{~cm}$ long $\times 20.0 \mathrm{~cm}$ wide $\times 6.5 \mathrm{~cm}$ tall) and covered with a snap-on plastic cap. The lids were cut in their upper part, where a fine white mesh fabric was fixed with acrylic glue on the inner surface. 
Anagasta kuehniella adults were collected daily over a 20-day period. These individuals were transferred to round plastic containers $(25.0 \mathrm{~cm}$ diameter $\times 19.0 \mathrm{~cm}$ tall $)$ covered with fabric and placed upside down on a plastic dish (30.0 cm diameter) for egg collection. Anagasta kuehniella eggs were collected, separated from the residues of this insect and stored at $1.8^{\circ} \mathrm{C}$.

\section{Anagasta kuehniella egg treatment}

A $10 \%$ nontoxic glue solution diluted in distilled water was used to fix forty-five 24-hour-old A. kuehniella eggs onto a piece of white paperboard $(2 \mathrm{~cm}$ wide $\times 4$ $\mathrm{cm}$ long) previously sterilized with UV light for $60 \mathrm{~min}$. and then immersed in a solution of each commercial product (Atrazina Atanor $50 \mathrm{SC}^{\circledR}$, Paradox ${ }^{\circledR}$ and Sanson $40 \mathrm{SC}^{\circledR}$ ) (Table 1) for two seconds. An Engeo Pleno ${ }^{\circledR}$ solution (Table 1) was used as a positive control, and pure distilled water was used as a negative control. Solutions of the products were prepared using distilled water, and their concentrations followed the recommendation of the respective manufacturers for utilization in corn crops. The two-second period was used because it was sufficient for complete egg immersion according to preliminary tests. The treated pieces of paperboard were left at $25 \pm 2{ }^{\circ} \mathrm{C}$ for 30 min. for excess water evaporation (Menezes et al., 2014). A paperboard piece with eggs that were treated 24 and 48 hours before and a 24-hour-old mated female of $T$. pretiosum were placed into individual glass test tubes $(2.5 \mathrm{~cm}$ wide $\times 8.5 \mathrm{~cm}$ long). These tubes were sealed with a cotton swab without food for the parasitoid. Parasitism was allowed for up to 48 hours. Engeo Pleno ${ }^{\circledR}$, with $\lambda$-cyhalothrin and thiamethoxam as the main active ingredients, was selected as a positive control due to its solution toxicity to Trichogramma galloi Zucchi, 1988 larvae on Diatraea saccharalis F., 1794 (Lepidoptera: Crambidae) eggs; treatment was performed by immersion for five seconds after parasitism (Antigo et al., 2013).

The experimental design was completely randomized, with five treatments consisting of the chemical products and the positive and negative control. Anagasta kuehniella eggs that were treated with the chemical solutions were stored for two storage periods (i.e., 24 and 48 hours). These eggs were offered to the parasitoids using two periods of egg offering (i.e., 24 and 48 hours). Ten replicates (each with one T. pretiosum female and $45 \mathrm{~A}$. kuehniella eggs) were used per treatment.

\section{Bioassay with Trichogramma pretiosum}

Trichogramma pretiosum longevity on alternative host eggs that had been treated with the chemical products 24 and 48 hours before parasitism was evaluated every 60 $\min$ for 48 hours. The dead females of this parasitoid were removed from the tubes at each evaluation.

Parasitized eggs were characterized by black colouration on the fifth day after exposure to parasitism. The percentage of alternative host eggs per sampling unit showing parasitoid emergence was evaluated three days after emergence.

Table 1: The commercial names (Com.) of the herbicides Atrazina Atanor 50 SC ${ }^{\circledR}$ (A.A.), Paradox ${ }^{\circledR}$ (P.), Sanson 40 $\mathrm{SC}^{\circledR}\left(\mathrm{S}\right.$.), and the insecticide Engeo Pleno ${ }^{\circledR}$ (E.P.) as the positive control (PC), active ingredient (a.i.; $\left.\mathrm{g} \mathrm{L}^{-1}\right)$, chemical group (Group), dose of the commercial product per hectare $\left(\mathrm{He}\right.$.; $\left.\mathrm{L} \mathrm{ha}^{-1}\right)$, dose of the commercial product per paperboard (Pa.; $\mu \mathrm{L}$ paperboard ${ }^{-1}$ ), and toxicology and formulation (Tox., Form.) of the chemical products used in the treatment of Anagasta kuehniella (Lepidoptera: Pyralidae) eggs pre-offered to parasitism by Trichogramma pretiosum (Hymenoptera: Trichogrammatidae).

\begin{tabular}{|c|c|c|c|c|c|}
\hline Com. & a.i. & Group & He. & Pa. & Tox. $^{2}$, Form. ${ }^{3}$ \\
\hline A.A. ${ }^{1}$ & Atrazine (500) & Triazines & 5.0 & 0.3 & TC: III, EC: III and CS \\
\hline P. ${ }^{1}$ & Paraquat dichloride (200) & Bipyridylium & 2.0 & 0.12 & TC: I, EC: II and CS \\
\hline S. ${ }^{1}$ & Nicosulfuron (40) & Sulfonylurea & 1.5 & 0.09 & TC: III, EC: III and CS \\
\hline E.P. ${ }^{1}(P C)$ & $\begin{array}{l}\lambda \text {-Cyhalothrin }(106)+ \\
\text { Thiamethoxam (141) }\end{array}$ & $\begin{array}{l}\text { Pyrethroid + } \\
\text { Neonicotinoid }\end{array}$ & 0.25 & 0.015 & TC: III, EC: I and CS \\
\hline
\end{tabular}

${ }^{1}$ Manufacturer (local): Atanor S.A.(Buenos Aires, Argentina)(website:http://www.adapar.pr.gov.br/arquivos/File/defis/DFI/Bulas/ Herbicidas/atrazinaatanor50_SC.pdf), Arysta LifeScience do Brasil Indústria Química e Agropecuária Ltda. (Salto de Pirapora, São Paulo state, Brazil) (website: http://www.adapar.pr.gov.br/arquivos/File/defis/DFl/Bulas/Herbicidas/paradox160318.pdf), Sinon Corporation (Taichung City, Taiwan) (website: http://www.adapar.pr.gov.br/arquivos/File/defis/DFI/Bulas/Herbicidas/ Sanson_40SC_2017.pdf), and Syngenta Proteção de Cultivos Ltda. (São Paulo, São Paulo state, Brazil) (website: http://www. adapar.pr.gov.br/arquivos/File/defis/DFI/Bulas/Inseticidas/ENGEOPLENOS010318.pdf), respectively. ${ }^{2}$ TC: toxicological class (I: extremely toxic, II: highly toxic, III: moderately toxic, and IV: slightly toxic). EC: environmental classification (I: highly dangerous, II: very dangerous, III: dangerous, and IV: slightly dangerous) according to the Ministério da Agricultura, Pecuária e Abastecimento (MAPA) of Brazil (MAPA, 2017). ${ }^{3}$ CS: concentrated suspension. 


\section{Data analysis}

Three bioassays were carried out to evaluate the longevity, parasitism and emergence of $T$. pretiosum. Every bioassay was repeated three times, and the results are presented as the means of the replicates. The data on T. pretiosum longevity, parasitism and emergence when presented with A. kuehniella eggs in the different treatments were corrected (Abbott, 1925) and classified as 1 - harmless (lower than $30 \%$ reduction), 2- slightly harmful (between 30 and $79 \%$ reduction), 3- moderately harmful (between 80 and 99\% reduction), and 4harmful (higher than $99 \%$ reduction) according to the International Organization for Biological Control (IOBC) (Sterk et al., 1999). These data were also submitted to analysis of variance (ANOVA), and the means were compared with the Scott-Knott test at 5\% probability (Scott; Knott, 1974) using the statistical program SISVAR, version 5.6 (Supplier: Universidade Federal de Lavras, Lavras, Minas Gerais state, Brazil) (Ferreira, 2011).

\section{RESULTS AND DISCUSSION}

\section{Trichogramma pretiosum longevity after parasitism on A. kuehniella eggs}

\section{Longevity at $\mathbf{2 4}$ hours post-treatment}

The longevity of $T$. pretiosum females submitted to parasitism of A. kuehniella eggs at 24 hours post-treatment with the products was similar between the herbicides and the controls, ranging from $18.00 \pm 3.22$ to $27.60 \pm 6.20$ hours for the treatments with nicosulfuron and paraquat dichloride, respectively (Table 2). The similar longevity of T. pretiosum on A. kuehniella eggs at 24 hours post-treatment suggests selectivity of the tested chemical products. However, this differs from reports of nicosulfuron being the most toxic herbicide in terms of adult survival and longevity of Trichogramma ostriniae Pang \& Chen, $1974\left(\mathrm{LC}_{50}=0.266\right.$ $\mathrm{mg} \mathrm{L}^{-1}$ ) and Trichogramma dendrolimi Matsumura, 1926 $\left(\mathrm{LC}_{50}=1.78 \mathrm{mg} \mathrm{L}^{-1}\right)$ after 24 hours of exposure to the dry residues of this herbicide, although there were some variations in toxicity between parasitoid species (Xu et al., 2013).

Table 2: Longevity in hours (mean \pm SE) of Trichogramma pretiosum (Hymenoptera: Trichogrammatidae) females, percentage of parasitized Anagasta kuehniella (Lepidoptera: Pyralidae) eggs $(\mathrm{N}=45)$ and their emergence (mean $\pm \mathrm{SE}$ ) after 24 and 48 hours of treatment (HT) with the following treatments (T): Atrazina Atanor 50 SC ${ }^{\circledR}$ (atrazine, triazines) (A.A.), Paradox ${ }^{\circledR}$ (paraquat dichloride, bipyridylium) (P.), Sanson $40 \mathrm{SC}^{\circledR}$ (nicosulfuron, sulfonylurea) (S.), and Engeo Pleno ${ }^{\circledR}$ ( $\lambda$-cyhalothrin + thiamethoxam, pyrethroid + neonicotinoid, respectively) (E.P.) as a positive control (PC) and distilled water (D.W.) as a negative control (NC), their mean with chemical products, reduction of parasitism (R., \%) and toxicological class (Class).

\begin{tabular}{|c|c|c|c|c|c|c|c|c|c|c|c|c|c|}
\hline \multirow[t]{2}{*}{$\mathrm{T}$} & \multirow[t]{2}{*}{ HT } & \multicolumn{12}{|c|}{ Variables } \\
\hline & & Longevity & Mean & $\mathrm{R}$. & Class & Parazitized eggs & Mean & R. & Class & Emergence & Mean & R. & Class \\
\hline \multirow[t]{2}{*}{ A.A. } & 24 & $24.00 \pm 3.09 a A$ & \multirow{2}{*}{16.80} & \multirow{2}{*}{28.20} & \multirow{2}{*}{1} & $19.70 \pm 2.78 \mathrm{aA}$ & \multirow{2}{*}{12.90} & \multirow{2}{*}{0} & \multirow{2}{*}{1} & $76.91 \pm 9.04 a \mathrm{~A}$ & \multirow{2}{*}{56.42} & \multirow{2}{*}{19.3} & \multirow{2}{*}{1} \\
\hline & 48 & $9.60 \pm 3.48 b B$ & & & & $6.10 \pm 2.57 \mathrm{bB}$ & & & & $35.94 \pm 14.80 b B$ & & & \\
\hline \multirow[t]{2}{*}{ P. } & 24 & $27.60 \pm 6.20 \mathrm{aA}$ & \multirow{2}{*}{24.00} & \multirow{2}{*}{0} & \multirow{2}{*}{1} & $18.20 \pm 2.83 \mathrm{aA}$ & \multirow{2}{*}{17.75} & \multirow{2}{*}{0} & \multirow{2}{*}{1} & $74.01 \pm 9.21 \mathrm{aA}$ & \multirow{2}{*}{72.22} & \multirow{2}{*}{0} & \multirow{2}{*}{1} \\
\hline & 48 & $20.40 \pm 2.56 a A$ & & & & $17.30 \pm 3.14 \mathrm{aA}$ & & & & $70.44 \pm 11.97 \mathrm{aA}$ & & & \\
\hline \multirow[t]{2}{*}{ S. } & 24 & $18.00 \pm 3.22 \mathrm{aA}$ & \multirow{2}{*}{16.80} & \multirow{2}{*}{28.20} & \multirow{2}{*}{1} & $0.10 \pm 0.01 \mathrm{bA}$ & \multirow{2}{*}{0.05} & \multirow{2}{*}{99.6} & \multirow{2}{*}{4} & $10.00 \pm 10.00 \mathrm{bA}$ & \multirow{2}{*}{5.00} & \multirow{2}{*}{92.8} & \multirow{2}{*}{3} \\
\hline & 48 & $15.60 \pm 3.60 \mathrm{bA}$ & & & & $0.00 \pm 0.00 \mathrm{cA}$ & & & & $0.00 \pm 0.00 \mathrm{cA}$ & & & \\
\hline \multirow[t]{2}{*}{ E.P. $(P C)$} & 24 & $20.40 \pm 5.38 a A$ & \multirow{2}{*}{23.40} & \multirow{2}{*}{0} & 1 & $0.42 \pm 0.01 \mathrm{bA}$ & 041 & 965 & 3 & $20.00 \pm 13.33 \mathrm{bA}$ & 8.48 & 593 & 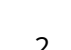 \\
\hline & 48 & $26.40 \pm 3.91 \mathrm{aA}$ & & & 1 & $0.47 \pm 0.01 \mathrm{cA}$ & 0.44 & & J & $36.97 \pm 15.27 \mathrm{bA}$ & 20.40 & נ.כנו & 2 \\
\hline D.W. (NC) & 24 & $20.40 \pm 2.56 \mathrm{aA}$ & & & & $16.70 \pm 2.75 \mathrm{aA}$ & & & & $75.73 \pm 10.03 a A$ & & & \\
\hline & 48 & $26.40 \pm 5.30 \mathrm{aA}$ & .70 & - & 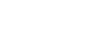 & $8.80 \pm 2.30 \mathrm{bB}$ & 12.1 & 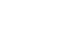 & 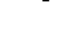 & $64.13 \pm 14.21 \mathrm{aA}$ & בנינש & 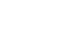 & - \\
\hline
\end{tabular}

*Means followed by the same lowercase (hours) or capital letter (treatments) in a column did not differ according to the ScottKnott test $(P<0.05)(S c o t t ;$ Knott, 1974); reduction $(\%)=1$ - (general mean of the product $\div$ general mean of negative control) (Abbott, 1925); classification of toxicity according to the International Organization for Biological Control (IOBC) (Sterk, 1999), class $1=$ harmless (<30\% reduction), class $2=$ slightly harmful (30 to $79 \%$ reduction), class $3=$ moderately harmful ( 80 to $99 \%$ reduction), and class $4=$ harmful ( $>99 \%$ reduction). 


\section{Longevity at 48 hours post-treatment}

The longevity of $T$. pretiosum females submitted to parasitism of $A$. kuehniella eggs at 48 hours posttreatment with the products was lowest with atrazine and nicosulfuron, with values of $9.60 \pm 3.48$ and $26.40 \pm 5.30$ hours for atrazine and the negative control, respectively (Table 2). The shorter longevity of $T$. pretiosum females at 48 hours post-treatment with atrazine and nicosulfuron demonstrates the persistence of these herbicides. Atrazine is highly toxic and persistent in the environment, as reported in the field, where it adversely affected sunflower, Helianthus annuus L. (Asteraceae), in areas previously cultivated with corn (Brighenti et al., 2002). However, this disagrees with the low toxicity of atrazine after 144 hours of exposure of $T$. pretiosum adults to the herbicide Primóleo ${ }^{\circledR}$ (herbicide, a.i. atrazine, group: triazine) (Stefanello Júnior et al., 2008) and of the effects of Sanson $40 \mathrm{SC}^{\circledR}$ and Primóleo ${ }^{\circledR}$ on the longevity of females of the gregarious endoparasitoid Palmistichus elaeisis Delvare \& La Salle, 1993 (Hymenoptera: Eulophidae) 48 hours after the parasitism of treated mealworms, Tenebrio molitor L., 1758 (Coleoptera: Tenebrionidae) pupae (Menezes et al., 2014).

\section{Longevity at 24 and 48 hours post-treatment}

The longevity of $T$. pretiosum females was similar at 24 and 48 hours post-treatment with the products and lowest with atrazine 48 hours post-treatment ( $9.60 \pm 3.48$ hours), with all the others and the controls classified as harmless (lower than 30\% reduction) (Table 2). The reduction in parasitism and emergence of $T$. pretiosum under the positive control (product containing $\lambda$-cyhalothrin + thiamethoxam) and the low impact on the longevity of this parasitoid agree with reports of low $\lambda$-cyhalothrin toxicity to $T$. pretiosum adults in terms of longevity 48 hours after parasitism on treated A. kuehniella eggs (Souza et al., 2013). Cyhalothrin sprayed onto the leaves of upland cotton, Gossypium hirsutum L. (Malvaceae) plants was innocuous to Trichogramma exiguum Pinto \& Platner, 1983 females four days after treatment (Suh; Orr; Van Duyn, 2000). On the other hand, of the chemicals tested, this insecticide was the most harmful to $T$. galloi larvae parasitizing $D$. saccharalis eggs immersed for five seconds after 24 hours of parasitism (Oliveira et al., 2013). The toxicity of $\lambda$-cyhalothrin to egg parasitoids depends on host susceptibility and the developmental stage of the target insect's nervous system because this pyrethroid acts by interrupting this system (Cônsoli; Parra; Hassan, 1998).
Parasitism of A. kuehniella eggs treated with $T$. pretiosum

\section{Parasitism of eggs at $\mathbf{2 4}$ hours post-treatment}

The number of eggs parasitized by T. pretiosum at 24 hours post-treatment with the chemical products was lowest with nicosulfuron and the positive control $(\lambda$-cyhalothrin + thiamethoxam), with values of $0.10 \pm 0.01$ and $19.70 \pm 2.78$ for nicosulfuron and atrazine, respectively (Table 2). The lowest parasitism rate of $T$. pretiosum under the positive control with $\lambda$-cyhalothrin + thiamethoxam and nicosulfuron when submitted to parasitism after 24 hours post-treatment of A. kuehniella eggs agrees with the reduction of greater than $30 \%$ of this parameter for this natural enemy when treated with $\lambda$-cyhalothrin (Stefanello Júnior et al., 2008). The parasitism of A. kuehniella eggs in the laboratory was lower for T. pretiosum adults after contact with the dry residues of Sanson $40 \mathrm{SC}^{\circledR}$ on glass plates (Stefanello Júnior et al., 2012). In addition, Sanson $40 \mathrm{SC}^{\circledR}$ reduced parasitism by P. elaeisis on T. molitor pupae after immersion for two seconds in a solution of this product (Menezes et al., 2014). However, nicosulfuron at the recommended dose had a low effect on the mortality and parasitism of $T$. pretiosum on eggs of the alternative host after immersion in the herbicide solution (Khan; Ruberson, 2017).

\section{Parasitism of eggs at $\mathbf{4 8}$ hours post-treatment}

The number of eggs parasitized by T. pretiosum at 48 hours post-treatment with the chemical products was lowest with nicosulfuron and the positive control $(\lambda$-cyhalothrin + thiamethoxam) and intermediate with atrazine and the negative control, with values ranging from $0.00 \pm 0.00$ to $17.30 \pm 3.14$ with nicosulfuron and paraquat dichloride, respectively (Table 2). The highest impact of nicosulfuron and the positive control based on $\lambda$-cyhalothrin + thiamethoxam on the parasitism of $T$. pretiosum on the eggs of the alternative host $A$. kuehniella at 48 hours post-treatment was due to the toxicity of these compounds to Trichogrammatidae. However, the effects of chemical products on T. pretiosum and other parasitoids of this group depend on their toxicity and may be enhanced by adjuvants and other compounds in their formulation (Menezes et al., 2014). This was shown by the lack of impact on the mortality of pupae and parasitism of subsequent generations of Trichogramma chilonis Ishii, 1941 when parasitizing rice moth, Corcyra cephalonica Stainton, 1866 (Lepidoptera: Pyralidae) eggs treated with the herbicides 2.4-DEE $38 \mathrm{EC}^{\circledR}$ (group: aryloxyalkanoic acid), imazosulfuron $10 \mathrm{SC}^{\circledR}$ (group: sulfonylureas), paraquat 
dichloride $24 \mathrm{SL}^{\circledR}$ (group: bipyridylium), pretilachlor 50 $\mathrm{EC}^{\circledR}$ (group: chloroacetamide), sulfosulfuron $75 \mathrm{WP}^{\circledR}$ (group: sulfonylureas), and sumisoya $50 \mathrm{WG}^{\circledR}$ (group: cyclohexene dicarboximide). This suggests that adjuvants and other compounds added to the herbicide solution enhance negative effects on Trichogrammatidae (Mandal; Debnath; Panja, 2006).

\section{Parasitism of eggs at 24 and 48 hours post-treatment}

The number of $A$. kuehniella eggs parasitized by T. pretiosum was lower at 48 hours post-treatment with atrazine and under the negative control. Nicosulfuron and the positive control $(\lambda$-cyhalothrin + thiamethoxam) were classified as class 4 (harmful, $>99 \%$ reduction) and class 3 (moderately harmful, 80 to $99 \%$ reduction), respectively (Table 2). A low impact of the paraquat dichloride herbicide on $T$. pretiosum parasitism was also reported for this herbicide when applied to $C$. cephalonica eggs after 96 hours of parasitism by $T$. chilonis, without affecting this parameter for this parasitoid (Mandal et al., 2006). This is likely due to the tolerance of this biocontrol agent to the active ingredient because paraquat dichloride was the most toxic to the parasitoid Telenomus remus Nixon, 1937 (Hymenoptera: Platygastridae) among the tested fungicides, herbicides and insecticides (Carmo; Bueno; Bueno, 2010). The parasitism of $A$. kuehniella eggs by $T$. pretiosum after contact with dry chemical product residues was lowest with Gramoxone $200^{\circledR}$ (herbicide, a.i. paraquat dichloride, group: bipyridylium) (Stefanello Júnior et al., 2008), and Gramocil ${ }^{\circledR}$ (herbicide, a.i. paraquat dichloride, group: bipyridylium) was innocuous to larvae of the endoparasitoid $T$. remus after treatment of $S$. frugiperda eggs submitted to parasitism (Carmo et al., 2009). The paraquat dichloride selectivity for $T$. pretiosum disagrees with the act from 2008 of the Agência Nacional de Vigilância Sanitária (ANVISA) of the Ministério da Saúde, Brasília, Brazil, which directed the toxicological re-evaluation of products formulated with this active ingredient via the Resolução da Diretoria Colegiada (RDC) No. 10. This was justified given that this active ingredient shows highly acute and chronic toxicity to farmers. In addition, RDC No. 190, dated November 30, 2017, published in the Diário Oficial da União No. 230 on December 1, 2017, declared that the importation of all products and formulations based on this active ingredient will be prohibited in Brazil beginning on September 22, 2020 (ANVISA, 2017). Paraquat dichloride is a non-selective herbicide with contact action and is recommended for use in weed control in exportation crops, such as Digitaria sanguinalis (L.) Scop. (Poaceae) control in corn, in addition to the control of Euphorbia heterophylla
L. (Euphorbiaceae) and Lolium multiflorum Lam. (Poaceae) in upland cotton, Cenchrus echinatus L. (Poaceae) and Portulaca oleracea L. (Caryophyllales) in coffee (Coffea; Rubiaceae), Brachiaria plantaginea (Link) Hitchc. (Poales) in soybean (Glycine max L. Merrill; Fabaceae), and Bidens pilosa L. (Asteraceae) and Galinsoga parviflora Cav. (Asteraceae) in wheat (ANVISA, 2017).

\section{Emergence of $T$. pretiosum from treated $A$. kuehniella eggs}

\section{Emergence from eggs at 24 hours post-treatment}

The emergence of $T$. pretiosum from eggs at 24 hours post-treatment was lowest with nicosulfuron and in the positive control ( $\lambda$-cyhalothrin + thiamethoxam), with values ranging from $10.00 \pm 10.00$ to $76.91 \pm 9.04 \%$ for nicosulfuron and atrazine, respectively (Table 2). The lowest emergence of T. pretiosum from A. kuehniella eggs submitted to parasitism at 24 hours post-treatment with the products containing nicosulfuron and $\lambda$-cyhalothrin + thiamethoxam differed from results showing the highest female emergence of this biocontrol agent and Trichogramma acacioi Brun, Moraes \& Soares, 1984 and Trichogrammatoidea annulata de Santis, 1972 from A. kuehniella eggs treated with nicosulfuron at $1.50 \mathrm{~L} \mathrm{ha}^{-1}$ than in the control with only distilled water but reduced female emergence of Trichogramma bruni Nagaraja, 1983 (Leite et al., 2016). Sanson $40 \mathrm{SC}^{\circledR}$ applied to glass plates in rearing cages with $T$. pretiosum adults was classified as selective for the emergence of this parasitoid from $A$. kuehniella eggs (Stefanello Júnior et al., 2008).

\section{Emergence from eggs at $\mathbf{4 8}$ hours post-treatment}

The emergence of $T$. pretiosum from eggs at 48 hours post-treatment was lowest with nicosulfuron and intermediate with atrazine and the positive control $(\lambda$-cyhalothrin + thiamethoxam), with values ranging from $0.00 \pm 0.00$ to $70.44 \pm 11.97$ for nicosulfuron and paraquat dichloride, respectively (Table 2). The lowest emergence of $T$. pretiosum from A. kuehniella eggs submitted to parasitism at 48 hours post-treatment with the product containing nicosulfuron differed from results showing the highest adult emergence of this parasitoid after contact with nicosulfuron applied to glass plates in rearing cages and their pre-submission to parasitism on eggs of this alternative host (Stefanello Júnior et al., 2008) and the larvae of this parasitoid on eggs of this moth treated with the same product after submission to parasitism (Leite et al., 2016), possibly due to the different forms of herbicide application. The first study evaluated the emergence of 
offspring whose host eggs were treated pre-parasitism with the herbicide, which may have slowly penetration into them (Hassan; Abdelgader, 2001), causing toxicity and reducing offspring emergence. The second and third studies, with lower risk to emergence, involved glass plates treated with the herbicide in adult rearing cages and eggs of the host treated post-parasitism, respectively. The parasitoid may have been protected by its own eggs in the third study. The mixture of Sanson $40 \mathrm{SC}^{\circledR}$ and Gesaprim $500 \mathrm{Ciba}$ Geigy $^{\circledR}$ (herbicide, a.i. atrazine, group: triazines) also showed no reduction in the emergence of $T$. pretiosum adults on post-treated A. kuehniella eggs (Leite et al., 2017). The classification of nicosulfuron as harmless (class $1,<30 \%$ reduction), having a low capacity to penetrate into the chorion of eggs of the alternative host, A. kuehniella, with low acidity $(\mathrm{pH}=6.09)$, a hydrophilic quality and a molecular weight of $410.4 \mathrm{mg} \mathrm{mol}^{-1}$ (Leite et al., 2016), is therefore questionable.

\section{Emergence from eggs at 24 and 48 hours post- treatment}

Trichogramma pretiosum emergence was lowest under atrazine at 48 hours post-treatment. Nicosulfuron was classified as class $3=$ moderately harmful ( 80 to $99 \%$ reduction), the positive control $(\lambda$-cyhalothrin + thiamethoxam) was classified as class $2=$ slightly harmful (30 to $79 \%$ reduction), and atrazine was classified as class $1=$ harmless (lower than $30 \%$ reduction) (Table 2 ). The lack of impact of atrazine on $T$. pretiosum emergence was similar to that reported for the herbicide Gesaprim 500 Ciba Geigy $^{\circledR}$ when sprayed onto A. kuehniella eggs subjected to parasitism (Leite et al., 2015). The higher emergence of $T$. pretiosum and $T$. remus from A. kuehniella and S. frugiperda eggs treated with the herbicide Paradox ${ }^{\circledR}$ than with Gramoxone $200^{\circledR}$ classified them as slightly harmful and selective, respectively (Carmo et al., 2009, 2010).

\section{CONCLUSIONS}

The products were classified as harmless to the longevity of $T$. pretiosum. On the other hand, the nicosulfuron-based product and the positive control with $\lambda$-cyhalothrin + thiamethoxam were classified as moderately harmful and harmful to parasitism, respectively, and as moderately harmful and slightly harmful to the emergence of $T$. pretiosum from $A$. kuehniella when offered for parasitism after 48 hours of egg treatment, respectively. Paraquat dichloride showed compatibility for the management of weeds in corn crops with biological control using $T$. pretiosum. This parasitoid coexists with several other natural enemies and non-target arthropod species in corn crops that could be affected negatively by herbicides. Even considering the low toxicity to the parasitoid species used in the present test, paraquat dichloride should be used carefully for the control of weeds in integrated pest management programmes in corn crops.

\section{ACKNOWLEDGEMENTS}

Phillip John Villani (University of Melbourne, Australia) and American Journal Experts (AJE) revised and corrected the English language used in an early and final version of this manuscript, respectively. The research was financially supported by the following Brazilian institutions Conselho Nacional de Desenvolvimento Científico e Tecnológico (CNPq), Coordenação de Aperfeiçoamento de Pessoal de Nível Superior (CAPES) - Finance Code 001, Fundação de Amparo à Pesquisa do Estado de Minas Gerais (FAPEMIG), and Programa Cooperativo sobre Proteção Florestal (PROTEF) of the Instituto de Pesquisas e Estudos Florestais (IPEF).

\section{REFERENCES}

ABBOTT, W. S. A method of computing the effectiveness of an insecticide. Journal of Economic Entomology, 18(2):265267, 1925.

AGÊNCIA NACIONAL DE VIGILÂNCIA SANITÁRIA (ANVISA). Voto $n^{\circ}$ 056/2017/DIREG/ANVISA. 2017. Available in http://portal.anvisa.gov.br/documents/219201/2782895/ Voto+Renato+Paraquate/fa409d90-a520-4302-9815f39b683da509. Access in January, 172017.

ALBAJES, R.; LUMBIERRES, B.; PONS, X. Responsiveness of arthropod herbivores and their natural enemies to modified weed management in corn. Environmental Entomology, 38(3):944-954, 2009.

ANDERSON, D. D. et al. Mechanism of primisulfuron resistance in a shattercane (Sorghum bicolor) biotype. Weed Science, 46(2):158-162, 1998.

ANTIGO, M. de R. et al. Repellence of pesticides used in sugarcane and their effects on the emergence of Trichogramma galloi. Revista Ciência Agronômica, 44(4):910-916, 2013.

BERNARDI, D. et al. Selection and characterization of Spodoptera frugiperda (Lepidoptera: Noctuidae) resistance to MON 89034 $\times$ TC1507 × NK603 maize technology. Crop Protection, 94(1):64-68, 2017. 
BRIGHENTI, A. M. et al. Persistence and phytotoxicity of the herbicide atrazine applied on corn crop on successive sunflower crop. Planta Daninha, 20(2):291-297, 2002.

CARMO, E. L. et al. Selectivity of different pesticides used in soybean to the eggs parasitoid Telenomus remus. Ciência Rural, 39(8):2293-2300, 2009.

CARMO, E. L. et al. Selectivity of pesticides used in soybean crops to Trichogramma pretiosum Riley, 1879 (Hymenoptera: Trichogrammatidae) pupae. Arquivos do Instituto Biológico, 77(2):283-290, 2010.

CARMO, E. L.; Bueno, A. F.; Bueno, R. C. O. F. Pesticide selectivity for the insect egg parasitoid Telenomus remus. BioControl, 55(4):455-464, 2010.

CASTILHO, R. V. et al. Selectivity of pesticides used in peach orchards on eggs and pupae of the predator Chrysoperla externa. Ciência Rural, 44(11):1921-1928, 2014.

CHEN, L. et al. Proteomic analysis of the bacterial induction of resistance to atrazine in soybean leaves. Acta Physiologiae Plantarum, 36(8):2229-2241, 2014.

CÔNSOLI, F. L.; PARRA, J. R. P.; HASSAN, S. A. Side effects of insecticides used in tomato fields on the egg parasitoid Trichogramma pretiosum Riley (Hym., Trichogrammatidae), a natural enemy of Tuta absoluta (Meyrick) (Lep., Gelechiidae). Journal of Applied Entomology, 122(1-5):43-47, 1998.

COUTO, C. A. et al. Performance of corn cultivars destined for green corn production and silage. Fronteiras: Journal of Social, Technological and Environmental Science, 6(1):232-251, 2017.

FERREIRA, D. F. Sisvar: A computer statistical analysis system. Ciência e Agrotecnologia, 35(6):1039-1042, 2011.

FUNDERBURK JR, H. H.; LAWRENCE, J. M. Mode of action and metabolism of diquat and paraquat. Weeds, 12(4):259264, 1964.

GIOLO, F. P. et al. Side-effects of pesticides used in integrated production of peache on Trichogramma pretiosum Riley, 1879 (Hymenoptera: Trichogrammatidae). Revista Brasileira de Fruticultura, 27(2):222-225, 2005.

GONRING, A. H. R. et al. Selectivity of insecticides to Podisus rostralis (Stal) (Heteroptera: Pentatomidae) predator of eucalyptus-defoliating caterpillars. Revista Árvore, 27(2):263-268, 2003.

HASSAN, S. A.; ABDELGADER, H. A sequential testing program to assess the effects of pesticides on Trichogramma cacoeciae Marchal (Hym., Trichogrammatidae). IOBC/WPRS Bulletin, 24(4):71-81, 2001.
KHAN, M. A.; RUBERSON, J. R. Lethal effects of selected novel pesticides on immature stages of Trichogramma pretiosum (Hymenoptera: Trichogrammatidae). Pest Management Science, 73(12):2465-2472, 2017.

KOZLOWSKI, L. A.; KOEHLER, H. S.; PITELLI, R. A. Times and extension of weed coexistence period of weeds interfering in corn (Zea mays) yield. Planta Daninha, 27(3):481-490, 2009.

LEITE, G. L. D. et al. Herbicide toxicity, selectivity and hormesis of nicosulfuron on 10 Trichogrammatidae (Hymenoptera) species parasitizing Anagasta (= Ephestia) kuehniella (Lepidoptera: Pyralidae) eggs. Journal of Environmental Science and Health, Part B: Pesticides, Food Contaminants, and Agricultural Wastes, 52(1):70-76, 2016.

LEITE, G. L. D. et al. Effects of atrazine-based herbicide on emergence and sex ratio of Trichogrammatidae (Hymenoptera). Florida Entomologist, 98(3):899-902, 2015.

LEITE, G. L. D. et al. Nicossulfuron plus atrazine herbicides and Trichogrammatidae (Hymenoptera) in no-choice test: Selectivity and hormesis. Bulletin of Environmental Contamination and Toxicology, 99(5):589-594, 2017.

MANDAL, S. K.; DEBNATH, M.; PANJA, S. Effect of some herbicides on egg parasitism and development of Trichogramma chilonis Ishii (Trichogrammatidae: Hymenoptera). Journal of Crop and Weed, 2(1):26-28, 2006.

MENEZES, C. W. G. et al. Selectivity of atrazine and nicosulfurom to Podisus nigrispinus (Heteroptera: Pentatomidae). Planta Daninha, 30(2):327-334, 2012a.

MENEZES, C. W. G. et al. Palmistichus elaeisis (Hymenoptera: Eulophidae) as an indicator of toxicity of herbicides registered for corn in Brazil. Chilean Journal of Agricultural Research, 74(3):361-365, 2014.

MENEZES, C. W. G.; SOARES, M. A. Impacts of the control of weeds and herbicides applied to natural enemies. Revista Brasileira de Herbicidas, 15(1):2-13, 2016.

MENEZES, C. W. G. et al. Reproductive and toxicological impacts of herbicides used in Eucalyptus culture in Brazil on the parasitoid Palmistichus elaeisis (Hymenoptera: Eulophidae). Weed Research, 52(6):520-525, 2012b.

MINISTÉRIO DA AGRICULTURA, PECUÁRIA E ABASTECIMENTO (MAPA). Available in: http://www.agricultura.gov.br/. Access in February, 132017.

OLIVEIRA, H. N. et al. Selectivity of insecticides used in the sugarcane on adults of Trichogramma galloi Zucchi (Hymenoptera: Trichogrammatidae). Bioscience Journal, 29(5):1267-1274, 2013. 
PASINI, R. A. et al. Residual action of pesticides sprayed on corn plants on Trichogramma pretiosum. Revista Ceres, 64(3):242-249, 2017b.

PASINI, R. A. et al. Persistence of desiccant herbicides applied to transgenic maize on Trichogramma pretiosum Riley, 1879 (Hymenoptera: Trichogrammatidae). Revista Ciência Agronômica, 48(1):175-181, 2017a.

PELLEGRINO, E.; BEDINI, S.; ERCOLI, L. Impact of genetically engineered maize on agronomic, environmental and toxicological traits: A meta-analysis of 21 years of field data. Scientific Reports, 8(3113):1-12, 2018.

SCOTT, A. J.; KNOTT, M. A cluster analysis method for grouping means in the analysis of variance. Biometrics, 30(3):507$512,1974$.

SOUZA, J. R. et al. Impact of insecticides used to control Spodoptera frugiperda (JE Smith) in corn on survival, sex ratio, and reproduction of Trichogramma pretiosum Riley offspring. Chilean Journal of Agricultural Research, 73(2):122-127, 2013.

STEFANELLO JÚNIOR, G. J. et al. Persistence of pesticides used in corn field to the parasitoid Trichogramma pretiosum Riley, 1879 (Hymenoptera: Trichogrammatidae). Ciência Rural, 42(1):17-23, 2012.
STEFANELLO JÚNIOR, G. J. et al. Selectivity of herbicides registered on corn to Trichogramma pretiosum (Hymenoptera: Trichogrammatidae). Planta Daninha, 26(2):343-351, 2008.

STERK, G. et al. Results of the seventh joint pesticide testing programme carried out by the IOBC/WPRS-Working Group 'Pesticides and Beneficial Organisms'. BioControl, 44(1):99117, 1999.

SUH, C. P. C.; ORR, D. B.; VAN DUYN, J. W. Effect of insecticides on Trichogramma exiguum (Trichogrammatidae: Hymenoptera) preimaginal development and adult survival. Journal of Economic Entomology, 93(3):577-583, 2000.

TAVARES, W. de S. et al. Potential use of Asteraceae extracts to control Spodoptera frugiperda (Lepidoptera: Noctuidae) and selectivity to their parasitoids Trichogramma pretiosum (Hymenoptera: Trichogrammatidae) and Telenomus remus (Hymenoptera: Scelionidae). Industrial Crops and Products, 30(3):384-388, 2009.

TAVARES, W. de S. et al. Handicraft using corn ear husk and pest damage affecting its production. Maydica, 61(1):1-9, 2016.

$\mathrm{XU}, \mathrm{H}$. Q. et al. Analysis and evaluation of eight herbicides toxicity and sensitivity against two Trichogramma spp. Journal of Food, Agriculture and Environment, 11(3-4):855-858, 2013. 